\title{
Medieval Lyric. Genres in Historical Context, Edited by William D. Paden
}

\section{Walter Meliga}

\section{(2) OpenEdition}

1 Journals

\section{Edizione digitale}

URL: https://journals.openedition.org/studifrancesi/38928

DOI: 10.4000/studifrancesi.38928

ISSN: 2421-5856

\section{Editore}

Rosenberg \& Sellier

\section{Edizione cartacea}

Data di pubblicazione: 1 décembre 2004

Paginazione: 333

ISSN: 0039-2944

\section{Notizia bibliografica digitale}

Walter Meliga, «Medieval Lyric. Genres in Historical Context, Edited by William D. Paden», Studi Francesi

[Online], 143 (XLVIII | II) | 2004, online dal 30 novembre 2015, consultato il 19 mai 2021. URL: http:// journals.openedition.org/studifrancesi/38928; DOI: https://doi.org/10.4000/studifrancesi.38928

Questo documento è stato generato automaticamente il 19 mai 2021.

\section{(c) $($ i) $(9)$}

Studi Francesi è distribuita con Licenza Creative Commons Attribuzione - Non commerciale - Non opere derivate 4.0 Internazionale. 


\title{
Medieval Lyric. Genres in Historical Context, Edited by William D. Paden
}

\author{
Walter Meliga
}

\section{NOTIZIA}

Medieval Lyric. Genres in Historical Context, Edited by William D. Paden, Urbana - Chicago, University of Illinois Press ("Illinois Medieval Studies"), 2000, pp. 371.

1 Il volume è un interessante reading sulla lirica medievale romanza, germanica, latina, ispano-araba ed ebraica e sui generi lirici, indagati nella loro corrispondenza con la concezione moderna e visti nel loro sviluppo storico e nei loro rapporti con la retorica e la musica. Fra i molti contributi, si segnalano: Douglas KELLY, The Poem as Art of Poetry: The Rethoric of Imitation in the Grand Chant Courtois (pp. 191-208); Elisabeth AUBREY, Genre as a Determinant of Melody in the Songs of the Troubadours and the Trouvères (pp. 273-296); Sylvia ниот, Intergeneric Play: The Pastourelle in the Thirteenth-Century French Motets (pp. 297-314). 